Jurnal Pena Sains Vol. 6, No. 1, April 2019

p-ISSN: 2407-2311

e-ISSN: 2527-7634

\title{
ANALYSIS OF LOCAL WISDOM TOWARD ENVIRONMENTAL CONSERVATIONATTITUDE IN BANGKALAN DISTRICT: A PRELIMINARY RESEARCH
}

\author{
Yunin Hidayati ${ }^{1}$ \\ ${ }^{1}$ Program Studi Pendidikan IPA Universitas Trunojoyo Madura \\ Bangkalan, 69162, Indonesia \\ yunin.hidayati@gmail.com
}

Accepted: February 25, 2019

Published: April 30, 2019

DOI: http://doi.org/10.21107/jps.v6i1.5257

\begin{abstract}
Based on the results and discussion previously described, the results can be concluded that local wisdom in Bangkalan district can be used to raise awareness of the importance of environmental conservation and the use of potential around the community. Suggestions that can be given is that it expected that research is developed for implementation in the field of education by including into one of the learning materials for example on the topic of environmental pollution.
\end{abstract}

Keywords: Attitude, Conservation, Local Wisdom.

\footnotetext{
${ }^{1}$ Corresponding Author
} 


\section{Hidayati}

\section{Introduction}

One of the hot issues discussed by many parties today is environmental problems. For example, climate change due to the greenhouse effect has implications for rising sea levels, which significantly affect people's lives. The interaction between humans and the environment does not always have a positive impact, sometimes causing adverse effects on ecosystems such as environmental damage, natural disasters, disasters, and other losses. This condition, local wisdom held by local communities can minimize the negative impacts that exist (Supriadi \& Agustin, 2017). Each region has different cultures, customs and values, and norms. The culture is generally unique and unique which is formed in a long period and is strongly influenced by environmental conditions, and vice versa, ecological conditions are also influenced by the existing culture. As time goes by, there is a shift and change in the culture which of course also affects the current environmental changes.

The branch of science that studies the distinctive knowledge of a particular culture and becomes local wisdom of that culture referred to as ethnoscience. The study of ethnoscience which is the focus of attention are the ways, rules, norms, values that allow or prohibit or direct how things should or should be done in the context of a particular culture. The culture is the result of people's thinking which poured into a tradition that continues to be maintained today (Sumarni, 2018).

The development of ethnoscience has become one of the essential parts of environmental sustainability so that it widely developed today. However, the culture learned in ethnoscience must follow specific procedures, and the truth can be tested empirically by following particular procedures (Sudarmin, Sumarti,
\& Woro Sumarni, 2018). That is a challenge for researchers because science in society is unstructured, not systematic, local and generally the result of knowledge of people's perceptions of a particular natural phenomenon - ethics in society, commonly known as the study of existing and distinctive local wisdom.

Local wisdom is any form of knowledge, belief, understanding, insight and custom or ethics that guides human behavior in life within an ecological community (Ernawati, Azrai, \& Wibowo, 2016), obtained from active adaptation to the environment (Hasbiah, 2015) rooted, fundamental, and a manifestation of behavior of a community to manage and maintain the environment wisely (Nasihuddin, 2017). Local wisdom has a profound meaning and is closely related to cultural values, especially religion, law, and norms that exist in a society that always maintained for generations. Local wisdom is part of the community to survive to live following environmental conditions by their needs and challenging to eliminate. Local wisdom is a manifestation of the behavior of specific societies or communities so that they can live side by side without having to destroy it. The function of local wisdom is first, a marker of the identity of a community that interacts with each other with the surrounding environment. Second, as an adhesive element (cohesive aspect) across citizens, across religions and beliefs. Third, local wisdom provides a color of togetherness for a community in carrying out activities. Fourth, change the mindset and reciprocal relationships of individuals and groups by putting it on the common ground of culture that owned. Fifth, encourage the establishment of togetherness, appreciation as well as a common mechanism to ward off the destructive possibilities, communal solidarity, which is believed to originate and grow on shared awareness, from an 


\section{Analysis of Local Wisdom Toward Environmental Conservation Attitude}

integrated community (Sufia, Amirudin, \& Sumarmi, 2016).

Local wisdom owned by thousands of tribes that distribute throughout Indonesia. The preservation of local wisdom arises and develops not explicitly and is generally traditional. Every community adapts and develops local wisdom as an experience for environmental management. Local wisdom about the environment can be seen from how humans treat objects, plants, animals, and whatever is around them.

The treatment involves the use of human reason so that from these activities illustrated how the mindset and attitude of the community in solving a problem. The accumulation of the results of social activities in addressing and treating the environment is called natural wisdom. Natural wisdom means describing how to behave and act humanly to respond to the changes in the environment (Gunawan, Digdoyo, \& Subarkah, 2014). Local wisdom in Bangkalan district, East Java is still quite felt and is still preserved by residents. Bangkalan as one of the districts in Madura is very thick with a religious and Islamic atmosphere. One that can be found with the number of Islamic boarding schools. At present, local wisdom, especially in Bangkalan district, is expected to be able to participate in preserving the existing environment. Bangkalan district produces large amounts of waste..

Waste is all kinds of building objects, goods, animals, or plants originating from human activities in fulfilling their life needs which can cause and or result in contamination of water, soil, and air so that it can cause environmental damage in the form of organic and inorganic waste (Rizal, 2011). Trash is the result of daily human activities and/or natural processes that are solid (Undang-Undang Republik
Indonesia tentang Pengelolaan Sampah, 2008). Because waste is the material produced by daily human activities, the amount of waste production will continue to increase, both from organic and inorganic waste types.

Increasing the amount of waste that is not followed by repairs and/or upgrading of waste facilities and infrastructure will create increasingly complex problems such as non-transported waste, illegal waste disposal, the city looks dirty, dirty, and dirty, causing unpleasant odors and causing illness. Reduce the capacity of the river, clog the drainage channel so that it can cause flooding. The amount of waste from each year is increasing according to table 1.

Table 1. Amount of garbage and population of Bangkalan

\begin{tabular}{ccc}
\hline Year & $\begin{array}{c}\text { Nmber of } \\
\text { Population }\end{array}$ & $\begin{array}{c}\text { Garbage } \\
\left(\mathrm{m}^{3} / \text { hari }\right)\end{array}$ \\
\hline 2006 & 926.562 & 200,72 \\
2007 & 935.920 & 205,83 \\
2008 & 946.215 & 210,01 \\
2009 & 967.191 & 220.70 \\
2010 & 968.596 & 232,32 \\
\hline
\end{tabular}

Source: BLH Kabupaten Bangkalan (dalam Iriani Ismail, 2011)

That can be a unique problem because in certain areas it is effortless to find rubbish, especially on the highways. The lack of insight into the conservation of the environment, especially towards waste, becomes a problem for the government and society. There needs to be optimal handling to handle these problems. Disposal of garbage carried out carelessly and not according to its place shown in figure 1 . 


\section{Hidayati}

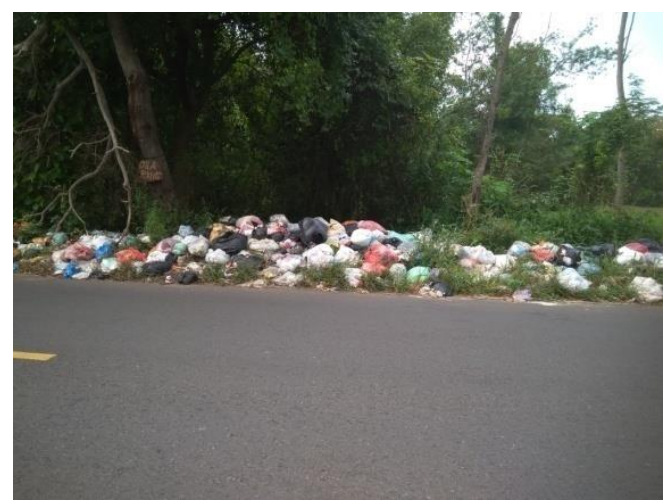

Figure 1. Careless garbage disposal

Various efforts have been made in waste management. In general, waste management includes collection, transportation and final harvesting activities. At the final disposal stage, garbage will experience specific processes both physically, chemically and biologically (Sulistiyorini, Darwis, \& Gutama, 2015). Community participation in waste management can increase awareness of the importance of environmental hygiene and strengthen community initiatives in maintaining the environment. The role of the community is needed to improve the spirit of ecological conservation, among others by providing socialization to the community, integrating waste in an integral and integrated manner, and enhancing the sense of protection by bringing up the values of local wisdom (Ismail, 2011).

However, every region has local wisdom that has been handed down from generation to generation and participates in preserving the existing environment. Research on the relation of local wisdom with environmental conservation is very necessary to maintain the current culture and of course to maintain the preservation of the environment. Traditional knowledge is increasingly forgotten and eroded due to a lack of understanding and awareness of preserving the environment and biodiversity (Nasihuddin, 2017)
Traditionally, the people in Bangkalan have traditional values related in their daily lives. For waste management, the majority of the treatment carried out is to dispose of waste and related use of materials in life. It can be seen from the use of natural materials that easily decomposed as materials for everyday life. For example, in the activity of wrapping food, it is attempted with content that easily decomposed, although it does not rule out the possibility of using plastic as a substitute for leaves.

The presence of plastic is undoubtedly able to simplify people's lives, but it is also inversely proportional to the impact produced because plastic is difficult to decompose and takes a long time in the decomposition process. The use of plastic waste can certainly be reduced if the community can preserve the surrounding environment. However, such matters need to be carried out indepth research to be able to participate in protecting the environment by utilizing local wisdom that has been formed for generations in Bangkalan. The behavior of pro-environment people is an essential aspect of a product's conservation. Related local wisdom to environmental conservation also influenced by the relationship between knowledge and attitudes towards ecological preservation (Darmawan \& Fadjarajani, 2016).

Three approaches can be done to develop environmental awareness namely education, integrate with socio-cultural communities, in this case, is local wisdom, and consistent in law enforcement related to waste management (Hasbiah, 2015). Environmental conservation is not only done in the agricultural environment but is carried out with the coastal environment in Gorontalo province (Katili, Utina, Tamu, \& Nusantari, 2018) north coast in the Tuban 


\section{Analysis of Local Wisdom Toward Environmental Conservation Attitude}

area of East Java (Putra, 2017), Galunggung mountains, Tasikmalaya, West Java (Darmawan \& Fadjarajani, 2016), Tigawasa Village, Buleleng, Bali (Ayu, Candraningsih, Bagus, Pujaastawa, \& Putu, 2018)

Various kinds of efforts are needed so that local wisdom can be internalized into people's lives so that the problems associated with waste can be overcome. The application of local wisdom in the community can protect the environment from damage. Local wisdom is an essential value to decide important decisions related to policies relating to the environment.

\section{Research Method}

The research method used is quantitative non-experimental ex post facto research. Popuplasi of this study is the community in Bangkalan district. The sampling technique was purposive sampling, while the data collection technique used questionnaires given to respondents as many as 34 people. Questionnaires in the form of structured questions contain community attitudes towards the value of local wisdom related to the environment, especially in waste management and processing of local potential in the form of products and waste produced.

Data collected includes questions about how to manage waste around the residence, the type of waste management, the local potential of the community, the possibility of local potential to produce waste, potential local processing. The focus of the research is conservation values, and local wisdom in Bangkalan Madura community and various activities carried out by the community to develop conservation attitudes towards the environment, especially in waste management. The data obtained was reduced, verified and conceptualized according to the local wisdom of the community related to environmental conservation.

\section{Result and Discussion}

Questionnaires were given to people in three different villages in Bangkalan. Respondent data obtained from the study included age, education level, gender, and occupation. Questionnaires were filled by 34 people with ages ranging from 17 to 80 years consisting of $44.1 \%$ female respondents and the remaining $55.9 \%$ male. Based on the age range and percentage of sexes, the questionnaire was distributed equally to men and women in the adult category. Based on the background of various work such as farmers, homemakers, and others.

The results of data analysis showed that the results of the answers related to waste management were found that $88.2 \%$ of respondents knew the processing of waste and the rest did not know. Waste that is not adequately processed is one of the contributors to environmental damage. If the problems related to global issues and environmental damage, so it should be considered globally and act locally (Sufia, Sumarmi, \& Amiruddin, 2016). Specifically, in Bangkalan, based on the results of the questionnaire, data were obtained that respondents stated that $96.9 \%$ of the waste processing methods were burned, $21.9 \%$ were buried, $15.6 \%$ were fertilized, and $3.1 \%$ were made biogas as shown in Figure 1. 


\section{Hidayati}

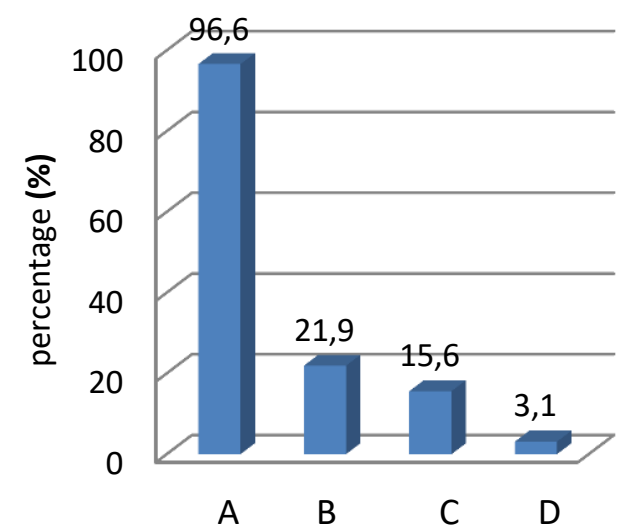

$\mathrm{A}=$ Burnt

$\mathrm{B}=$ Buried

$\mathrm{C}=$ Composted

$\mathrm{D}=$ Processed into biogas

Figure 1. Treatment of garbage

Burning garbage in rural areas is indeed common because besides the open land is still extensive, knowledge of waste processing so that it can be used as something useful is still lacking. It is burning done because it is practical and easy to do. The process of combustion of waste produces $\mathrm{CO}$ and $\mathrm{CH}_{4}$ gas emissions (Octavia, Fitrianingsih, \& Jati, 2015) Meanwhile, the amount of biogas production is the smallest, even though biogas is an energy producer that can be utilized in daily life which can be obtained from recycling waste (Sunyoto, Danang Dwi Saputro, 2016).

It is related to the process of separating organic and inorganic waste. Almost half of which were $47.1 \%$ of respondents did not know the process of separating organic waste from waste organic. It is partly due to a lack of understanding of respondents to the differences in organic waste with inorganic waste and the different processing processes. Many of these wastes are disposed of carelessly or thrown in the sea so that it has the potential to cause land, water, and air pollution. Madura region, especially in Bangkalan, also has local potential, namely, agriculture reaching $73.5 \%$ and second place is batik as much as $20.6 \%$. Agriculture that used uses local wisdom in the community, for example, the existence of the "Je' Bumi" tradition as a ritual in the framework of expressing gratitude when it comes to carrying out activities related to lands such as when planting in rice fields or gardens. Also, the tradition of rokat tase' also carried out, namely a ritual in the framework of gratitude for the blessings that are received, especially sea products.

The process of activities related to agriculture must pay attention to the values inherited from their ancestors. Land use must follow natural signs and and not use land that is out of habit and prevailing norms (Ernawati et al., 2016) Based on the knowledge, beliefs, understanding and habits or ethics of applying local wisdom leads human behavior in life to be wiser in its ecological community to protect the conservation of natural resources. For batik, based on hereditary knowledge in utilizing natural resources which are natural coloring agents (Tresnawati, 2018).

The type of processing of agricultural products which is processed by local potential based on that amounted to $44.1 \%$ through a preservation process by the customs and cultural customs of the community $(55.9 \%)$. Preservation is carried out traditionally including drying and utilization of local salt. Preservation was done by drying, disinfecting and salting especially for products related to agriculture. The preservation process, for example, is carried out on shrimp paste products which are typical traditions of Tanjung Bumi village (Hadi, Sari, Sugiharto, \& Mawaddah, 2018).

Preservation with salvation is a tradition of local wisdom that has been carried out from ancient times. Pro- 


\section{Analysis of Local Wisdom Toward Environmental Conservation Attitude}

environment community behavior is an essential aspect of nature conservation (Putra, 2017). This case study conducted in a village that is still thick with traditional nuances. Food processing and all kinds of citizen production are traditionally carried out by local potential that has been carried out for generations. $\mathrm{T}$

There is a relationship between environmental knowledge and behavior in maintaining environmental cleanliness. Namely, there is an attitude of concern for the environment that positively correlated with nature conservation. The waste produced is mostly also organic waste which tends to decompose quickly. No special handling of the waste produced. The organic waste should still be able to be processed into fertilizer so that it can be used more by the community.

\section{Conclusion}

Based on the results and discussion previously described, the results can be concluded that it can be concluded that local wisdom in Bangkalan district can be used to raise awareness of the importance of environmental conservation and the use of potential around the community. Suggestions that can be given is that it expected that research is developed for implementation in the field of education by including into one of the learning materials for example on the topic of environmental pollution.

\section{References}

Ayu, I., Candraningsih, K., Bagus, I., Pujaastawa, G., \& Putu, I. G. (2018). Konservasi Hutan Berbasis Kearifan Lokal di Desa Tigawasa, Kecamatan Banjar , Kabupaten Buleleng. Jurnal Humanis, 22(2), 311-319.
https://doi.org/10.24843/JH.2018.v2 2.i02.p06

Darmawan, D., \& Fadjarajani, S. (2016). Hubungan antara pengetahuan dan sikap pelestarian lingkungan dengan perilaku wisatawan dalam menjaga kebersihan lingkungan. Jurnal Geografi, 4(24), 37-49.

Ernawati, Azrai, E. P., \& Wibowo, S. S. (2016). Hubungan Persepsi Kearifan Lokal Dengan Sikap Konservasi Masyarakat Desa Lencoh Kecamatan Selo Di Taman Nasional Gunung Merapi. Biosfer: Jurnal Pendidikan Biologi (biosferjpb), 9(1), 65-69.

Gunawan, R., Digdoyo, E., \& Subarkah, A. (2014). Budaya Keraifan Lokal Dalam. Jurnal Sejarah Dan Budaya, 8(2), 207-214.

Hadi, W. P., Sari, F. P., Sugiharto, A., \& Mawaddah, W. (2018). Studi etnosains terasi sebagai sumber belajar IPA berbasis kearifan lokal. In National Conference on Mathematics, Science, and Education (pp. 343-348).

Hasbiah, A. (2015). Analysis of Local Wisdom As An Environmental Conservation Strategy In Indonesia. Journal Sampurasun, 01(01), 2-7.

Ismail, Ii. (2011). Prospek Pengelolaan Sampah Non-Konvensional Di Bangkalan. In Prosiding SNaPP2011 Sains, Teknologi, dan Kesehatan (pp. 181-188). Bandung.

Katili, A. S., Utina, R., Tamu, Y., \& Nusantari, E. (2018). Management of coastal biodiversity based on social-cultural values in constructing conservation character education. Biodiversitas, 19(5), 1763-1768. https://doi.org/10.13057/biodiv/d190 
Melestarikan Lingkungan Hidup ( Studi Kasus Masyarakat Adat Desa Kemiren Kecamatan Glagah Kabupaten BanyuwangI ). Jurnal Pendidikan, 1(4), 726-731.

(2018). Local Wisdom in Environmental Conservation Local Wisdom in Environmental Conservation. In IOP Conf. Series: Earth and Environmental Science. IOP Publishing.

Nasihuddin, A. A. (2017). Kearifan lokal dalam perlindungan dan pengelolaan lingkungan hidup (studi di desa janggolan, banyumas). Bina Hukum Lingkungan, 2(1), 18-20. https://doi.org/10.24970/jbhl.v2n1.9

Octavia, D., Fitrianingsih, Y., \& Jati, D. R. (2015). Analisis Beban Emisi CO Dan $\mathrm{CH}_{4}$ Dari Kegiatan Pembakaran Sampah Rumah Tangga Secara Terbuka. Jurnal Teknologi Lingkungan Lahan Basah, 1(1), 110 .

Putra, D. F. (2017). Faktor Yang Mempengaruhi Perilaku Peduli Lingkungan Masyarakat Pesisir (Studi Kasus Pesisir Desa Jenu Kabupaten Tuban). Jurnal Pendidikan Dan Ilmu Geografi, 2(1), 117-126.

Rizal, M. (2011). Analisis Pengelolaan Sampah Perkotaan (Sudi kasus pada Kelurahan Boya Kecamatan Banawa Kabupaten Donggala). Jurnal Smartek, 9(2), 155-172.

Sudarmin, Sumarti, S. S., \& Woro Sumarni. (2018). Model Pembelajaran Kimia Organik Bahan Alam Berpendekatan Science Technology Engineering and Mathematics (STEM) Terintegrasi Etnosains (1st ed.). Semarang: Unnes Press.

Sufia, R., Amirudin, A., \& Sumarmi. (2016). Kearifan Lokal Dalam
Sulistiyorini, N. R., Darwis, R. S., \& Gutama, A. S. (2015). Partisipasi Masyarakat Dalam Pengelolaan Sampah Di Lingkungan Margaluyu Kelurahan Cicurug. SHARE SOCIAL WORK JURNAL, 5(1), 7180 .

Sumarni, W. (2018). Etnosains Dalam Pembelajaran Kimia Prinsip, Pengembangan dan Implementasinya. (Sudarmin, Ed.) (1st ed.). Semarang: Unnes Press.

Sunyoto, Danang Dwi Saputro, S. (2016). Pengolahan sampah organik menggunakan reaktor biogas di kabupaten kendal. Rekayasa Vol. 14 No. 1, 14(1), 29-36.

Supriadi, D., \& Agustin, H. (2017). The Use Of Local Wisdom In Sustaining Environmental Conservation: A Study On Environmental Communication Activities In Sindangkerta Village, Cipatujah, The Province Of West Java, Indonesia. In The 9th International Graduate School and Scholars Conference in Indonesia (pp. 1935). Yogyakarta: The Graduate School of Universitas Gajah Mada.

Tresnawati, N. (2018). Pembelajaran Sains Berbasis Kearifan Lokal dalam Upaya Peningkatan Konservasi Lingkungan pada Mahasiswa PGSD di Batik Tulis Ciwaringin Cirebon. AL IBTIDA: JURNAL PENDIDIKAN GURU MI, 5(1), 69-82.

Undang-Undang Republik Indonesia 
tentang Pengelolaan Sampah (2008).

Indonesia.

Zamzami, L., \& Effendi, N. (2018). The

Local Wisdom In Marine Resource Conservation In Indonesia: A Case

Study Of Newcomers In

PariamanWest Sumatra. In

Advances in Social Science, Education and Humanities Research (Vol. 136, pp. 391-400). 